УДК 615.1:658.7

DOI https://doi.org/10.11603/2312-0967.2020.2.11182

\title{
СУЧАСНІ АНАЛІТИЧНІ ПІДХОДИ ДО ВИЯВЛЕННЯ ФАЛЬСИФІКОВАНИХ ЛІКАРСЬКИХ ЗАСОБІВ
}

\author{
Г. С. Ейбен \\ Національний медичний університет імені О. О. Богомольця, Київ \\ eiben@ukr.net
}

ІНФОРМАЦІЯ

Надійшла до редакції / Received: 14.05.2020

Після доопрацювання / Revised: 27.05.2020

Прийнято до друку / Accepted 28.05.2020

\section{Ключові слова:}

фральсисрікація лікарських засобів;

візуальний контроль;

аналітичні методи контролю;

протидія;

виявлення;

роздрібна та оптова реалізація ліків;

якість та безпека лікарського засобу.
АНОТАЦІЯ

Мета роботи. Провести аналіз сучасних аналітичних технологій виявлення фральсифрікованих лікарських засобів та обґрунтувати науково-практичні підходи щодо їх використання під час оптової та роздрібної реалізації лікарських засобів.

Матеріали і методи. Дані вітчизняних і зарубіжних джерел щодо сучасних аналітичних методів контролю ліків, вітчизняні нормативно-правові акти у ссрері обігу та контролю лікарських засобів, аналітичні методи фрармацевтичного аналізу; аналіз логічний, структурний, порівняльний, експертна оцінка, узагальнення і систематизація.

Результати й обговорення. Встановлено, що візуальні методи виявлення сральсифрікованих ліків під час контролю якості лікарських засобів в аптечних закладах на сьогодні $€$ малоефективними. Візуальна оцінка дозволяє виявляти лише грубі підробки за зовнішніми ознаками упаковки та самого препарату. Сучасний досконалий рівень виготовлення фральсифрікованих лікарських засобів потребує на сьогодні впровадження в практику інноваційних технологій контролю ліків, які дають можливість з високою вірогідністю відрізнити підробку від оригіналу. Сучасні аналітичні методи виступають як ефективний засіб швидкого і надійного моніторингу якості лікарських засобів при здійсненні їх контролю. У статті наведено сутність та квалісрікаційні ознаки доступних у використанні та обслуговуванні аналітичних методів та устаткування, що застосовуються при проведенні контролю ліків в економічно розвинутих країнах, а також можуть бути рекомендовані для використання в Україні.

Висновки. Проведений аналіз сучасних технологічних підходів до виявлення фральсифрікованих лікарських засобів свідчить про необхідність доповнення візуальних методів контролю якості ліків у вітчизняних аптечних закладах сучасними аналітичними методами експрес-аналізу з метою підвищення якості та безпеки фрармацевтичної допомоги населенню.
Вступ. Фальсифрікація орармацевтичної продукції $€$ серйозною проблемою у сорері охорони суспільного здоров'я як на міжнародному, так і на національному рівні, особливо у країнах з низьким та середнім рівнем доходів. В Україні витрати державного бюджету на охорону здоров'я як частка ВВП наразі залишаються стабільно низькими. Так, за останні роки вони становили до 3 \%, що значно нижче середнього показника для країн Європейського регіону ВООЗ (5 \%) та ЄC (6 \%) [1]. Нині жодна країна світу не захищена

ISSN 2312-0967. Pharmaceutical review. 2020. № 2 
Організація роботи аптечних підприємств

\section{Organization of pharmaceutical structures' work}

повністю від появи на фрармацевтичному ринку фральсифрікованих лікарських засобів (ФЛЗ). У США обсяг ФЛЗ сягає $5 \%$, у країнах ЄС у середньому - $8 \%$ [2]. За даними Держслужби України з лікарських засобів (л3) та контролю за наркотиками (Держлікслужба), в Україні обіг ФЛЗ становить не більше $2 \%$ [3]. Достовірність цих даних викликає сумніви, так як їх величина на декілька порядків менше, ніж відповідні показники ФЛЗ у країнах ЄС. Інше джерело вказує на 15 $25 \%$ ФЛЗ, вірогідно ці цифри є істотно завищені. В Україні офріційні дані щодо кількості ФЛз відображають лише кількість виявлених в обігу ФЛЗ, а не кількість наявних, не визначені реальні обсяги ФЛЗ, що пов'язано з відсутністю єдиної системи моніторингу обігу ЛЗ та недосконалістю механізму існуючої системи контролю якості ЛЗ. Помилкові дані щодо наявності в обігу ФЛз як завищені, так і занижені, перешкоджають контрольно-регуляторним та правоохоронним органам адекватно протидіяти цьому ганебному явищу [4].

Сьогодні вже надзвичайно складно виявити фальсиорікат лише методом візуального контролю, який дозволяє встановити лише грубі підробки [5]. При цьому цей вид контролю лз лідирує в аптечних закладах України. Останнім часом спостерігається все більш високий рівень виготовлення ФЛЗ, і навіть досвідченому фахівцю складно за зовнішніми ознаками упаковки і самого препарату відрізнити підробку від оригіналу. Для есрективності боротьби з поширенням ФЛЗ на фрармацевтичному ринку України необхідні інноваційні аналітичні технології, що дозволяють тестувати на ідентичність лз у місцях їх реалізації та зберігання, тобто в аптечних закладах [6]. 3 огляду на динамічність змін на вітчизняному фрармацевтичному ринку і велике коло фракторів, що впливають на розвиток кримінального фрармацевтичного бізнесу, досліджувана у статті проблематика є актуальною та соціально значущою. Підтвердженням актуальності розробки системи швидкого виявлення ФЛЗ на осно- ві новітніх аналітичних технологій є підписання Україною Конвенції Ради Європи про підроблення медичної продукції та подібні злочини, що загрожують охороні здоров'я (Конвенція Medicrime). Цей міжнародний договір в Україні вступив в законну силу з 1 січня 2016 року $[7,8]$.

Мета роботи - провести аналіз сучасних аналітичних технологій виявлення фральсифрікованих лікарських засобів та обґрунтувати науково-практичні підходи щодо їх використання під час оптової та роздрібної реалізації лікарських засобів.

Матеріали і методи. Дані вітчизняних та зарубіжних джерел щодо сучасних аналітичних методів, вітчизняні нормативно-правові акти у сорері обігу та контролю лікарських засобів, аналітичні методики та устаткування для проведення фрармацевтичного аналізу; аналіз логічний, структурний, порівняльний, експертна оцінка, узагальнення і систематизація.

Результати й обговорення. Значною проблемою національного фрармацевтичного ринку є фральсифікація ЛЗ. Проведений аналіз за період з 01.01.2008 p. по 01.01.2019 р. показав, що в Україні виявлено в обігу 530 серій 301 найменування ФЛ3, з яких $63 \%$ це вітчизняні препарати, 37 \% - зарубіжні, тобто препарати вітчизняних виробників підробляють частіше. На сьогодні в Україні фральсиорікуються лз майже всіх фрармакотерапевтичних груп - кардіологічні, гормональні, протигрибкові, дерматологічні препарати, анальгетики. Однак лідирують у структурі підробок антибіотики, на частку яких припадає майже половина всіх виявлених ФЛЗ. Невідповідність за показниками якості в загальній кількості ФЛЗ, вилучених впродовж 2009-2014 років в Україні, представлено на рисунку 1.

За даними рисунка 1 найбільша кількість ФЛЗ була виявлена за показниками «Опис», «Упаковка», «Маркування» та «Ідентифрікація активного фрармацевтичного інгредієнту». За даними дослідження встановлено, що частіше підроблялися ЛЗ, що відпускають-

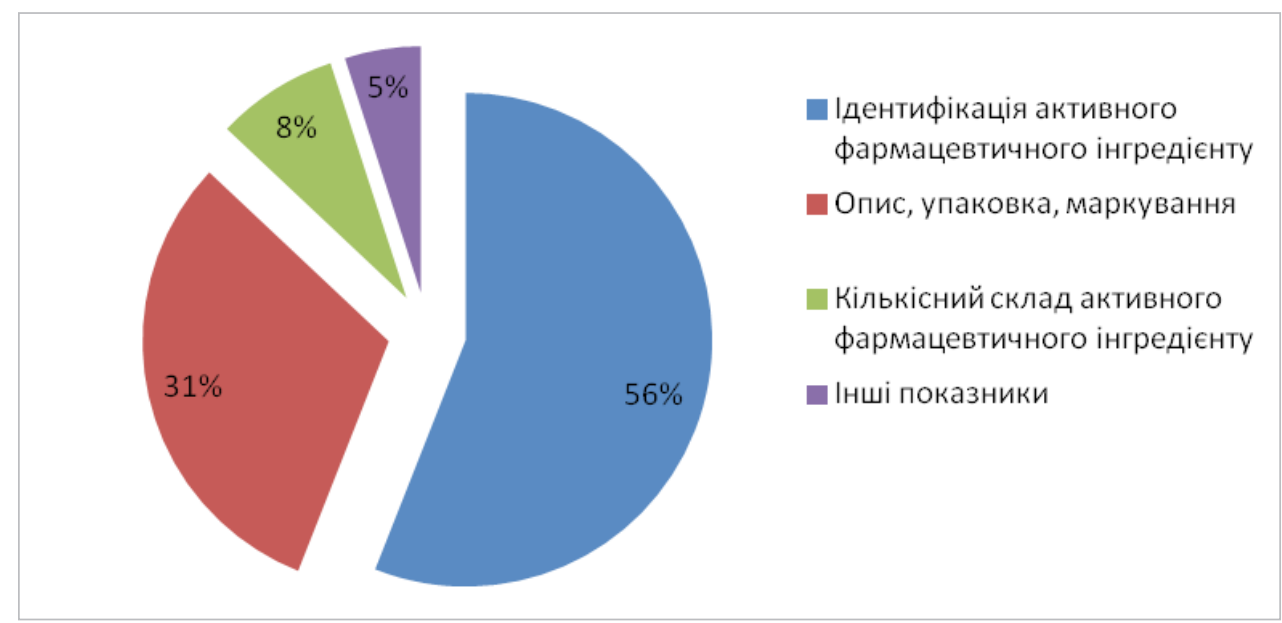

Рис. 1. Розподіл ФЛз за показниками невідповідності якості, вилучених з обігу на фрармацевтичному ринку України.

ISSN 2312-0967. Фармацевтичний часопис. 2020. № 2 
ся за рецептом (60\%), ніж безрецептурні ліки. За формою випуску найбільше виявлено лЗ для зовнішнього застосування, твердих лікарських фрорм та ін'єкційних ЛЗ.

Нами проведено системний аналіз аналітичних методів виявлення ФЛЗ, що на сьогодні використовуються у багатьох країнах світу. При цьому увагу зосереджено не на описі техніки виконання конкретних аналізів, а на можливості використання цих методів для раціональних методик аналізу лз, які надходять в аптечні заклади. ВООЗ наголошує, що внаслідок збільшення кількості ФЛЗ особливу увагу треба приділяти контролю якості ліків у системі їх поширення. 3 метою прискорення проведення ідентифрікації великої кількості проб лЗ ВООЗ рекомендує використовувати аналітичні експрес-тести для скринінгу якості ліків $[9,10]$. Під час проведення заходів, спрямованих на боротьбу 3 фральсифрікацією ЛЗ, необхідно брати до уваги, що витрати пов'язані з проведенням скринінгового оцінювання, слід співвідносити із суттєвими витратами, ймовірними внаслідок шкідливого впливу ФЛЗ на організм хворої людини, та навіть загибелі хворого [11].

Забезпечення належної якості ЛЗ у вітчизняних аптечних закладах суттєво залежить від дієвості та ефективності вхідного візуального контролю, який проводять уповноважені особи. При здійсненні вхідного контролю необхідна реалізація комбінованої оцінки якості ЛЗ, яка дозволяє виявити фральсифрікати, тобто доступними простими експресними аналітичними методами при мінімальній затраті часу проведення на аналіз (скринінгова оцінка). Необхідно визначити, що експрес-аналіз дозволяє проводити лише первинний скринінг ЛЗ для виявлення фральсифрікації Лз. Головне призначення скринінгу полягає в ідентифікації активного фрармацевтичного інгредієнта (АФІ). Цей вид дослідження не замінює фармакопейний, а доповнює його, для остаточного підтвердження результатів аналізу, потрібний лабораторний контроль відповідності потенційних ФЛЗ до вимог реєстраційного досьє. Існує кілька методів аналізу Л3. Залежно від поставлених завдань фрармацевтичний аналіз включає різні форми контролю якості ЛЗ. Якісні аналізи можуть бути використані для швидкого виявлення повністю шахрайської фрармацевтичної продукції, у яких діюча речовина відсутня, замість неї використовуються невідомі компоненти. Результати ідентифікації не розраховані на підтвердження хімічної структури молекули хімічної речовини або складу лікарської фрорми. Вони призначені для підтвердження з прийнятним ступенем достовірності того, що продукт відповідає інформації, наведеній на етикетці упаковки ЛЗ. Кількісний аналіз дозволяє виявити такі невідповідності якості, як недопустимий високий рівень домішок або неприйнятно низький або високий кількісний вміст діючої речовини. Уповноважена особа аптечного закладу може ви- значити невідповідність якості ЛЗ при їхньому візуальному огляді.

В останні роки злочинці навчилися створювати дуже точні репродукції упаковок ліцензованих лЗ. Фальсифікатори $з$ дивовижною точністю копіюють голограми, штрих-коди, кольори та маркування блістерів, фрлаконів і тому подібне. Як показує практика, лише мікроскопічний аналіз упаковки дозволяє виявити деякі дуже ретельно оформлені копії: під час збільшення відмінності друку на підробленій упаковці стають помітними. Тому візуальний огляд ЛЗ не гарантує в більшості випадків виявлення ФЛЗ. В поєднанні з кольоровими реакціями та реакціями осаду візуальний метод контролю якості Л3 дає більше можливостей для виявлення підробок. Необхідно взяти до уваги, що кольорові реакції і реакції осаду $є$ специфічними для підтвердження тотожності більшості фрармацевтичних субстанцій. Слід зазначити, що кольорові реакції дозволяють визначити активну речовину лікарської форми, але не забезпечують кількісну оцінку і не дозволяють встановити будь-які інші інгредієнти, які можуть бути присутні у фральсифрікованому препараті.

Тонкошарова хроматографрія (TШX) є найпоширенішим аналітичним скринінговим методом, який може використовуватись при проведенні вхідного контролю якості ЛЗ. ТШХ - це швидкий, простий, недорогий та надзвичайно універсальний метод, але він руйнує зразок і потребує попередньої підготовки проби ЛЗ.

Спектроскопія у ближній інфрачервоній області (ближня ІЧ-спектроскопія) характеризується тим, що кожен Лз має свій характерний спектр. Застосовується для ідентифікації та кількісної оцінки активних інгредієнтів та допоміжних речовин. Ближня ІЧспектроскопія є одним з основних сучасних аналітичних методів для швидкої і надійної ідентифрікації лікарських активних речовин. Метод не вимагає підготовки зразків, випромінювання може проходити через лікарські форми в блістерних упаковках, тобто не руйнують препарат. Портативні, акумуляторні інфрачервоні спектрометри є більш доступною альтернативою традиційним спектрометрам.

Раман-спектроскопія - цей метод може бути використаний для аналізу твердих та рідких лікарських фрорм. Раман-спектроскопія дозволяє проводити якісний і кількісний аналіз лз без пошкодження упаковки. Останні конструкції портативних спектрометрів дозволили значно збільшити кількість аналізів Л3 із метою раннього виявлення потенційного фальсифікату. Метод швидкий і не вимагає підготовки зразків, випромінювання може проходити через зразки у блістерних упаковках. Досвід розвинутих країн показує, що для ефективного виявлення ФЛЗ із найкращого боку зарекомендували себе із наявного портативного обладнання GPHF-MiniLab, ІЧ-спектрометр (NIR), Раман-спектрометр (TruScan) [12]. Портативні

ISSN 2312-0967. Pharmaceutical review. 2020. № 2 
Організація роботи аптечних підприємств

\section{Organization of pharmaceutical structures' work}

технології виявлення ФЛЗ, які можуть бути рекомендовані до використанні в аптечних закладах України, представлені в таблиці 1.

GPHF - MiniLab (тест - набір) - це мобільна лабораторія, що повністю вміщується у дві захисні валізи. Наявний ресурс дозволяє перевірити 80 сполук. Один комплект містить достатню кількість матеріалів для аналізу приблизно 1000 тестових знаків [13]. Важливим прогресом $є$ поява порівняно недорогого портативного ІЧ-спектрометра (NIR), його практичне використання показує високі результати у виявленні ФЛ3, що сприяє більш швидкому тестуванню великої кількості медикаментів у ланцюзі поставок. Портативний Раман-спектрометр (TruScan) є корисним інструментом для аналізу таких твердих Л3, як таблетки, капсули та субстанції. Раман-спектроскопія дозволяє легко ідентифікувати багато лікарських субстанцій та надати додаткову інфрормацію про допоміжні речовини, а також про відносне кількісне співвідношення АФІ та допоміжних речовин. Отже, сучасні портативні технології $€$ перспективним та ефективним засобом протидії фальсифікації Лз, які дозволяють тестувати ліки на всіх етапах обігу: від виробників до дистриб'юторів та аптечної мережі.

Поєднання швидких аналітичних технологій та сучасних методів захисту від проникнення фральсисрікованої продукції у фрармацевтичні, логістичні ланцюги повинні забезпечувати набагато вищий рівень безпеки медикаментів під час їх реалізації. Доступ злодіїв до високопродуктивного обладнання і сучасних фрармацевтичних технологій, недосконале законодавство, яке регламентує національну державну політику у сорері контролю якості ЛЗ, потребує впроваджен- ня есрективних заходів виявлення ФЛЗ. При цьому «Інструкція про порядок контролю якості ЛЗ під час оптової та роздрібної реалізації лікарських засобів», затверджена наказом МО3 України № 677 від 29.09.2014 р., при здійсненні вхідного контролю передбачає лише візуальний метод, хоча підробки ліків настільки досконалі, що візуально практично неможливо відрізнити фральсифрікат від оригіналу. Серед першочергових кроків, які сприяють ефективному виявленню ФЛз, є впровадження дворівневого підходу при здійсненні вхідного контролю якості ЛЗ по ланцюгу поставок аптечні склади - аптеки. Рекомендований підхід складається 3 двох послідовних взаємодоповнюючих рівнів аналізу: перший рівень включає візуальний огляд стану упаковки, а також фрізичних характеристик. На другому рівні застосовуються швидкі аналітичні тести, які можуть використовуватись при перевірках аптечних закладів територіальними органами Держлікслужби та уповноваженими особами, відповідальними за якість ЛЗ у суб'єктах фармацевтичної діяльності. Такий підхід дає можливість Україні, як країні з обмеженими матеріальними ресурсами, застосувати економічно есрективну технологію високої пропускної здатності для моніторингу якості Лз із забезпеченням достовірних результатів.

Таким чином, результати системного огляду сучасних аналітичних методів дають підстави стверджувати, що експресні аналітичні методи контролю, завдяки простоті виконання, доступності реагентів, оптимальному поєднанню хімічних і фрізико-хімічних методів, $€$ особливо корисними як первинний захід виявлення ФЛЗ і зміцнюють систему забезпечення якості

\section{Таблиця 1}

Портативні технології для виявлення фральсифікованих лікарських засобів

\begin{tabular}{|c|c|c|c|c|c|}
\hline Технологія & Продуктивність & Швидкість & Назва приладу & Переваги & Недоліки \\
\hline $\begin{array}{l}\text { Ближня } \\
\text { ІЧ-спектро- } \\
\text { скопія }\end{array}$ & Висока & Висока & $\begin{array}{l}\text { Портативний } \\
\text { IЧ - спектрометр } \\
\text { (NIR) }\end{array}$ & $\begin{array}{l}\text { Не потребує } \\
\text { попередньої } \\
\text { підготовки проби лз, } \\
\text { не руйнує дослідний } \\
\text { зразок ЛЗ. } \\
\text { Використання у } \\
\text { польових умовах }\end{array}$ & $\begin{array}{l}\text { Потребує } \\
\text { постійного } \\
\text { оновлення } \\
\text { бібліотеки } \\
\text { еталонних спектрів } \\
\text { л3 }\end{array}$ \\
\hline $\begin{array}{l}\text { Раман- } \\
\text { спектроскопія }\end{array}$ & Висока & Висока & $\begin{array}{l}\text { Портативний } \\
\text { Раман- } \\
\text { спектрометр } \\
\text { (TruScan) }\end{array}$ & $\begin{array}{l}\text { Не потребує } \\
\text { попередньої } \\
\text { підготовки проби лЗ, } \\
\text { не руйнує дослідний } \\
\text { зразок ЛЗ }\end{array}$ & $\begin{array}{l}\text { Висока вартість } \\
\text { приладу. } \\
\text { Потребує } \\
\text { постійного } \\
\text { оновлення } \\
\text { бібліотеки } \\
\text { еталонних спектрів } \\
\text { л3 }\end{array}$ \\
\hline $\begin{array}{l}\text { Система } \\
\text { швидкої } \\
\text { хімічної } \\
\text { ідентифрікації } \\
\text { (тест-набір) }\end{array}$ & Висока & Висока & $\begin{array}{l}\text { Портативний } \\
\text { GPHF-MiniLab }\end{array}$ & $\begin{array}{l}\text { Використання у } \\
\text { польових умовах }\end{array}$ & $\begin{array}{l}\text { Руйнує дослідний } \\
\text { зразок. } \\
\text { Потребує } \\
\text { попередньої } \\
\text { підготовки проби }\end{array}$ \\
\hline
\end{tabular}

ISSN 2312-0967. Фармацевтичний часопис. 2020. № 2 
Л3, мінімізуючи поширення ФЛЗ на національному фрармацевтичному ринку.

Висновки. Отже, розробка та впровадження у практику ефрективних методів виявлення ФЛЗ $€$ важливою задачею, спрямованою на забезпечення належних стандартів фармацевтичних послуг в Україні. Аналіз сучасних аналітичних підходів до здійснення контролю під час оптової та роздрібної реалізації Л3 показав, що візуальний метод контролю ЛЗ необхідно доповнити уніфрікованими доступними та експресними аналітичними методами для ідентифрікації ФЛЗ. Для подальшого вдо- сконалення механізму виявлення ФЛЗ при проведенні контролю в аптечних закладах доцільно оптимізувати нормативно-правову базу у сорері обігу та контролю Лз на вітчизняному фрармацевтичному ринку. Комплексний характер використання сучасних технологій виявлення ФЛЗ у поєднанні 3 правовими та організаційними заходами дозволить надійно захистити ліки від фральсифікації та гарантувати споживачу їх належну якість.

Конфлікт інтересів: відсутній.

Conflicts of interest: author has no conflict of interest to declare.

\title{
MODERN ANALYTICAL APPROACHES TO THE DETECTION OF COUNTERFEIT MEDICINES
}

\author{
H. S. Eiben \\ O. Bohomolets National Medical University \\ eiben@ukr.net
}

The aim of the work. To analyze modern analytical technologies for detection of counterfeit drugs and to substantiate scientific and practical approaches to their use during wholesale and retail sales of medicines.

Materials and Methods. Data from domestic and foreign sources on modern analytical methods of control of medicines, domestic regulations in the field of control of medicines, analytical methods of pharmaceutical analysis; logical, structural, comparative analysis, expert evaluation, generalization and systematization.

Results and Discussion. It is established that visual methods of detecting counterfeit drugs during quality control of medicines in pharmacies are currently ineffective. Visual assessment allows detecting only gross counterfeit drugs on the basis of external signs of packaging and the drug itself. Today's advanced level of manufacturing counterfeit medicines requires the introduction into practice of innovative drug control technologies that make it possible to distinguish counterfeit medicines from the original with a high probability. Modern analytical methods act as an effective means of rapid and reliable monitoring of the quality of drugs in their control. The article presents the essence of available in the use and maintenance of analytical methods and equipment used in drug control in economically developed countries, and can also be recommended for use in Ukraine.

Conclusions. The analysis of modern technological approaches to the detection of counterfeit drugs indicates the need to supplement the visual methods of quality control of drugs in domestic pharmacies by modern analytical methods of express analysis in order to improve the quality and safety of pharmaceutical care.

Key words: falsification of medicines; visual control; analytical methods of control; counteraction; detection; wholesale and retail sale of medicines; quality and safety of medicines.

\section{СОВРЕМЕННЫЕ АНАЛИТИЧЕСКИЕ ПОДХОДЫ ВЫЯВЛЕНИЯ ФАЛЬСИФИЦИРОВАННЫХ ЛЕКАРСТВЕННЫХ СРЕДСТВ}

\author{
А. С. Эйбен \\ Национальный медицинский университет имени А. А. Богомольца, Киев \\ eiben@ukr.net
}

Цель работы. Провести анализ современных аналитических технологий выявления фральсифицированных лекарственных средств и обосновать научно-практические подходы по их использованию во время оптовой и розничной реализации лекарственных средств.

Материалы и методы. Данные отечественных и зарубежных источников о современных аналитических методах контроля лекарств, отечественные нормативно-правовые акты в сфере обращения и контроля лекарственных средств, аналитические методы фрармацевтического анализа; анализ логический, структурный, сравнительный, экспертная оценка, обобщение и систематизация.

Результаты и обсуждение. Установлено, что визуальные методы выявления фральсисрицрованных лекарств во время контроля качества лекарственных средств в аптечных учреждениях в настоящее время являются

ISSN 2312-0967. Pharmaceutical review. 2020. № 2 
малоэффрективными. Визуальная оценка позволяет выявлять только грубые подделки по внешним признакам упаковки и самого продукта. Современный совершенный уровень изготовления фральсифицированных лекарственных средств требует сегодня внедрения в практику инновационных технологий контроля лекарств, которые дают возможность с высокой вероятностью отличить подделку от оригинала. Современные аналитические методы выступают как эффрективное средство быстрого и надежного мониторинга качества лекарственных средств при осуществлении их контроля. В статье описаны суть и квалисрикационные характеристики доступных в использовании и обслуживании аналитических методов и оборудования, применяемых при проведении контроля лекарств в экономически развитых странах, а также могут быть рекомендованы для использования в Украине.

Выводы. Проведенный анализ современных технологических подходов к выявлению фральсисрицированных лекарственных средств свидетельствует о необходимости дополнения визуальных методов контроля качества лекарств в отечественных аптечных учреждениях современными аналитическими методами экспресс-анализа с целью повышения качества и безопасности фрармацевтической помощи населению.

Ключевые слова: фральсификация лекарственных средств; визуальный контроль; аналитические методы контроля; противодействие; выявление; розничная и оптовая реализация лекарств; качество и безопасность лекарственного средства.

\section{Список бібліографічних посилань}

1. Global Health Observatory $(\mathrm{GHO})$ data. [Electronic resource]. - URL : https://www.who.int/gho/database/ en/.

2. WHO Global Surveillance and Monitoring System for substandard and falsified medical products. World Health Organization, 2017. - [Electronic resource]. URL : https://www.who.int/medicines/regulation/ssffc/ publications/GSMSreport_EN.pdf?ua=1.

3. Державна служби України з лікарських засобів та контролю за наркотиками. URL : http://dls.gov.ua/.

4. Лебедь С. О. Історичні аспекти та сучасний стан фральсифрікації лікарських засобів в Україні. Рівне : Волин. обереги, 2018. С. 219-251.

5. Гуторова Н. Відповідальність за фральсифрікацію лікарських засобів: чи створена в Україні належна правова база? URL : https://www.apteka.ua/ article/485029?fbclid=IwAR3oVCZfquoE3zPyj3rgwPIx A7e0ACkzvUp1zM65 8IITX6D-5JdsKulsHo.

6. Technologies for detecting falsified and substandard drugs in low and middle-income countries [Electronic resource]. S. Kovacs, S. Hawes, S. Maley, E. Mosites, L. Wong, A. Stergachis. PLoS Med. 2014. No. 9 (3). URL : http://journals.plos.org/plosmedicine/ article?id=10.1371/journal.pmed.1001388.

7. Конвенція Ради Європи про підроблення медичної продукції та подібні злочини, що загрожують охороні здоров'я від 28.10.2011 p. URL : https://zakon. rada. gov.ua/laws/show/994_a91.

8. Про ратисрікацію Конвенції Ради Європи про підроблення медичної продукції та подібні злочини, що загрожують охороні здоров'я: Закон України від 07.06.2012 p. № 4908-VI. URL : https://zakon.rada. gov.ua/laws/show/4908-17\#n2

9. FDA's Anti-Counterfeit Device, 2013. [Electronic resource]. URL : http://www.hhs.gov/open/initiatives/hhsinnovates/round6/fda-anti-counterfeit-device.html.

10. Spurious/Falsely-labelled/falseified/counterfeit (SFFC) medicines. World Health Organization, 2017. [Electronic resource]. URL : http://www.who.int/medicines/ services/counterfeit/en/.

11. PQM: Promoting the Quality Medicines in Developing Countries - [Electronic resource]. URL : http://www. usp.org/global-health-impact-programs/promotingquality-medicines-pqmusaid.

12. Counterfeit drugs: analytical techniques for their identification [Electronic resource]. R. Martino, M. MaletMartino, V. Gilard, Balayssac. Anal. Bioanal. Chem. 2010. Vol. 398. P. 77-92. URL : https://link.springer. com/article/10.1007/s00216-010-3748-y

13. The GPHF Minilab-Protection against counterfeit medicines. [Electronic resource]. URL : http://www.gphf.org/ web/en/minilab

\section{References}

1. Global Health Observatory (GHO) data. [Electronic resource]. Available from: https://www.who.int/gho/database/en/.

2. World Health Organization. WHO Global Surveillance and Monitoring System for substandard and falsified medical products. [Electronic resource]. Available from: https://www.who.int/medicines/regulation/ssffc/publications/GSMSreport_EN.pdf?ua=1

3. State service of Ukraine on medicines and drugs control. [Electronic resource]. Available from: http://dls.gov. ual. Ukrainian.

4. Lebed SO. Historical aspects and current state of drug falsification in Ukraine. [Історичні аспекти та сучасний стан фральсифрікації лікарських засобів в Україні] Rivne: Volyn. Oberehy; 2018. Ukrainian.

5. Gutorova N. Responsibility for falsification of medicines: whether a proper legal framework has been created in Ukraine? [Відповідальність за фральсифрікацію лікарських засобів: чи створена в Україні належна правова база?] Available from: https://www.apteka.ua/ article/485029?fbclid=IwAR3oVCZfquoE3zPyj3rgwPIx A7e0ACkzvUp1zM65_8IITX6D-5JdsKulsHo. Ukrainian.

ISSN 2312-0967. Фармацевтичний часопис. 2020. № 2 
6. Kovacs S, Hawes S, Maley S, Mosites E, Wong L, Stergachis A. Technologies for detecting falsified and substandard drugs in low and middle-income countries [Electronic resource]. PLoS Med. 2014;9(3). Available from: http://journals.plos.org/plosmedicine/ article?id=10.1371/ journal.pmed.1001388.

7. Council of Europe Convention on the Counterfeiting of Medical Devices and Similar Crimes Threatening Health from 28.10.2011 [Electronic resource]. Available from: https://zakon.rada.gov.ua/laws/show/994_a91. Ukrainian.

8. Low of Ukraine "On ratification of the Council of Europe Convention on Counterfeiting of Medical Devices and Similar Crimes Threatening Health" from June, 2012 No. 4908-VI. [Electronic resource]. Available from: https://zakon.rada.gov.ua/laws/show/4908-17\#n2. Ukrainian.

9. FDA's Anti-Counterfeit Device, 2013. [Electronic resource]. Available from: http://www.hhs.gov/open/initia- tives/hhsinnovates/round6/fda-anti-counterfeit-device. html.

10. World Health Organization. Spurious/Falsely-labelled/ falseified/counterfeit (SFFC) medicines. [Electronic resource]. Available from: http://www.who.int/medicines/ services/counterfeit/en/.

11. PQM: Promoting the Quality Medicines in Developing Countries. - [Electronic resource]. Available from: http://www.usp.org/global-health-impact-programs/ promoting-quality-medicines-pqmusaid.

12. Martino R, Malet-Martino M, Gilard V, Balayssac S. Counterfeit drugs: analytical techniques for their identification [Electronic resource]. Anal Bioanal Chem. 2010;398: 77-92. Available from: https://link.springer. com/article/10.1007/s00216-010-3748-y.

13. The GPHF Minilab -Protection against counterfeit medicines. [Electronic resource]. Available from: http:// www.gphf.org/web/en/minilab.

\section{Відомості про автора}

Ейбен Г. С. - канд. фрармац. наук, доцент кафедри організації та економіки фрармації, Національний медичний університет імені О.О. Богомольця, Київ. E-mail: eiben@ukr.net, ORCID 0000-0002-6537-5706.

\section{Information about the author}

Eiben H. S. - PhD (Pharmacy), Associate Professor of the Department of Organization and Economy of Pharmacy, O. Bohomolets National Medical University, Kyiv. E-mail: eiben@ukr.net, ORCID 0000-0002-6537-5706. 